\title{
ACTUALIDAD BIBLIOGRÁFICA SOBRE INMIGRACIÓN Y REFUGIO
}

\author{
CARMEN SANTOS AGUADO \\ M. ${ }^{a}$ JESÚS VEGA PASCUAL \\ SOCORRO ESCOBAR RUBIO \\ ANA M. ${ }^{\text {a ORTIZ DUQUE }}$
}

ACNUR: Directrices del ACNUR sobre asistencia a los refugiados impedidos. 1992.

ACNUR: Guía para la evaluación y cuidados de las víctimas de la violencia y traumatismos psíquicos. ACNUR. 1993

ACNUR: Guía para la protección de las mujeres refugiadas. 1991.

ACNUR: Interpretación en el contexto jurídico de los refugiados. Formación ACNUR. 1993.

ACNUR: La situación de los refugiados en el mundo 1995: en busca de soluciones. Alianza Editorial. 1995.

ACNUR y OMS: Mental health of refugees. Publicación conjunta de ACNUR y OMS. 1994.

Annual Review of Sociology: Refugees, inmigrants and the State. Annual Review of Sociology, 19. 43-59. 1993.

Asociación de Solidaridad con el Trabajador Inmigrante: Documentación Jornadas: Vivir en familia. Un derecho del trabajador inmigrante. Madrid, 1994.

CALVO BUEZAS, TOMÁS: El racismo que viene. Tecnos. Madrid, 1990.

Cáritas Española: «El desafío de 1992 y los emigrantes. La acción social». Cuadernos de Formación, núm. 29. Cáritas Española. Madrid, 1992.

Cáritas Española: Hacia la interculturalidad. 1996.

Cirem: «Educar a la diversitat. La presència de cultures no europees a Catalunya». Revista Infancia, educar de 0 a 6 anys, núm. 57. Barcelona, 1990. 
CIS (Centro de Investigaciones Sociológicas): «Actitudes ante el extranjero, Iberoamérica y la CEE». Reis, núm. 50. Madrid, 1990.

Colectivo IOE - Fundación Friedich Ebert, Instituto Fe y Seguridad: Inmigrantes en España, marco interpretativo de las principales tendencias. Madrid, 1992.

Colectivo IOE y Asociación de Solidaridad con trabajadores inmigrantes: «Inmigrantes: aportes para una crónica». Revista Exodo, núm. 4. Madrid, 1990.

Collecció Serveis Socials: Informe sobre el treball social amb inmigrans estranges a la província de Barcelona. Collecció Serveis Socials, 8. Diputació de Barcelona. Servei de Serveis Socials, 1992.

Cuadernos INASS, n. ${ }^{\circ}$ 11: Una experiencia de T. S. con refugiados. 1983.

Cruz Roja Española: Guía Práctica para el trabajador inmigrante. Asamblea Provincial de Cáceres, 1994.

DIEZ NICOLÁS, JUAN: «Los españoles ante la inmigración». Alfez 91-92. Madrid, 1992.

EDA, C.; DE PRADA, M.A. y otros: Los hijos de los inmigrantes. Madrid, 1991.

Editorial Libros P.M.: Ciudadano Mohamed. Barcelona, 1996.

ENTRENA DURÁN, FRANCISCO y otros: Los refugiados en Espa$\tilde{n} a$. IEPALA. Edita INSERSO. 1994.

Federación Española de Municipios y Provincias: Los municipios y la integración social de los inmigrantes. Análisis y propuestas de actuación. 1995.

Federación Internacional de Sociedades de la Cruz Roja y la Media Luna Roja: Guía para la planificación de operaciones en favor de los refugiados, personas desplazadas y repatriados. Ginebra, 1993.

Federación Internacional de Sociedades de la Cruz Roja y la Media Luna Roja: Asistencia a las personas de distintas culturas víctimas de la violencia organizada. 1995.

FROMICE, ADELA y LÓPEZ CABANAS, MIGUEL: Loa municipios y la integración social de los inmigrantes: análisis y propues- 
tas de actuación. FEMP (Federación Española de Municipios y Provincias). 1996.

Fundación La Caixa: La integración de los inmigrantes marroquies: familias marroquíes de la Comunidad de Madrid. Edita Fundación La Caixa. 1996.

Grupo PASS: Los refugiados y el reto de la inserción. Asociación Católica Española de Migración. 1995.

IEPALA: Guía de recursos para los refugiados en España. Edita INSERSO. 1995.

JUDITH HORVATH-LINDERG y DIANA MISEREZ: $E l$ trabajo con refugiados y solicitantes de asilo. Edita: Cruz Roja EspañolaINSERSO. 1994.

KAPTAN MARCUSÁN, ADRIANA (coord.): Procesos migratorios y relaciones interétnicas. IV Simposio del VII Congreso de Antropología Social. Zaragoza, 1996.

LIRA, E. y CASTILLO, M.I.: Consecuencias psicocsociales y políticas del miedo. En suplementos Antropos, 44. 1994

LÓPEZ GARCÍA, BERNABÉ: La inmigración marroquí en España. Relación entre la geografía de origen y la de destino. 1993.

LÓPEZ GARCÍA, BERNABÉ y 65 colaboradores: Atlas de inmigración magrebí en España. Centro de Estudios Internacionales Mediterráneos. Centro Internacional Carlos V. 1996.

MARTÍN BARÓ, IGNACIO: Guerra y trauma psicosocial del niño salvadoreño. Revista Antropos, 156. 1994

MARTÍN BERISTÁIN, C. y RIERA: Salud mental: «La comunidad como apoyo». Ed. Virus. Barcelona, 1992.

Médicos del Mundo: Guía de la población inmigrante en la Comunidad de Madrid. Patrocina la Consejería de Salud de la CAM. 1995.

M. ${ }^{\circ}$ AA.SS.: Boletín de inmigración y refugio. Area de Relaciones Institucionales. Madrid, 1994.

Revista Cuadernos de T.S.: Una propuesta para el T.S. con refugiados. Revista Cuadernos de T.S., núm. 6. Universidad Complutense, 1993.

Revista de la Delegación Diocesana ASTI: Las migraciones retos a la sociedad y a la iglesia. 1994. 
Revista de Trabajo Social: Las migraciones desde el Trabajo Social. Colegio Oficial de Diplomados en Trabajo Social y A.A.S.S. de Madrid. Monográfico primer trimestre. 1996.

Revista Minusval: Los refugiados en España. Revista Munsval, núm 87, pp. 21 a 63. M. ${ }^{\circ}$ A.A.S.S. 1996.

ROSA BONDIA, JORGE: «El papel de la educación en una sociedad multicultural». L'interculturalisme en el curriculum: el racisme. Rosa Sensat. Barcelona, 1991.

Secretariado de la Comisión Independiente sobre Asuntos Humanitarios Internacionales: El desafío del ser humano. Edita: INSERSO. 1989.

Secretariado de la Comisión Independiente sobre Asuntos Humanitarios Internacionales: Los refugiados: dinámica y desplazamiento. Edita: INSERSO. 1989.

TORRES, RAFAEL: «Yo Mohamed». Historias de inmigrantes en un país de emigrantes. Madrid, 1995. 